\title{
Correlation Between Detraining During the Covid-19 Pandemic and Ability of the Body Agility of Karate UKM Athletes State University of Malang
}

\author{
Latifatul Mufida \\ Fakultas Ilmu Keolahragaan \\ Universitas Negeri Malang \\ Malang, Indonesia \\ latifatulmufida4@gmail.com
}

\author{
Olivia Andiana \\ Fakultas Ilmu Keolahragaan \\ Universitas Negeri Malang \\ Malang, Indonesia
}

\author{
Ahmad Abdullah* \\ Fakultas Ilmu Keolahragaan \\ Universitas Negeri Malang \\ Malang, Indonesia
}

\begin{abstract}
Detraining is a decrease in the body's physiological adaptation caused by stopping exercise done for a relatively long time so that it affects a person's physical fitness performance. The effects of the Covid-19 pandemic make a person change their lifestyle to be less active, thus affecting the body's physiological capacity. This affects a person's health status and performance when carrying out their daily activities. One of them is affecting the athlete's performance on the agility of their body movements. The purpose of this study was to determine the relationship between detraining and the ability to agile body movements of Karate UKM athletes, State University of Malang. This research method uses correlational quantitative with causal design. The number of respondents in this study were 19 athletes of UKM Karate State University of Malang with certain criteria. The results of the study using the Spearman analysis technique with the help of the IBM SPSS 25.0 computer application obtained a p-value of 0,000 , and the correlation coefficient value obtained was 0.876 which was interpreted with the strength of the relationship at a very strong level. Based on the results of the research that has been done, it can be concluded that the incidence of detraining has a significant relationship to the level of agility of the Karate UKM athletes, State University of Malang. This is due to the lack of physical activity during the Covid-19 pandemic, which affects the body's physiological system, especially the strength and quality of muscle contraction, which ultimately affects the agility of the body.
\end{abstract}

Keywords—Detraining, Agility, Karate.

\section{INTRODUCTION}

The COVID-19 pandemic is currenty causing a global pandemic with a very high number of infected people dying. So that at the beginning of 2020 the Indonesian government carried out large-scale social restrictions or so-called PSBB (Ministry of Home Affairs, 2020). The effect of this can limit the activities carried out daily. Among them are reduced physical activity and unhealthy eating patterns that have a negative effect on the body [2]. When a person does not do regular physical activity, the physiological system in the body will adapt, thereby reducing the body's physiological capacity. This condition is said to be detraining

Detraining namely a decrease or loss of body physiological adaptation caused by stopping and resting training for a relatively long time so that it affects physical fitness performance, this does not only happen to athletes but to all sports players.

In research [3] It is said that athletes who experience detraining for 2 weeks will affect the decrease in sprint ability in the Yo-yo intermittent recovery test. This condition can be restored when the athlete starts training again intensively for 3 weeks. This is in line with other studies which show that detraining results in a significant reduction in physical fitness and muscle mass. Another impact of detraining is that it can affect the performance of the body during exercise and can cause a decrease in energy on the performance of kinematic motion [4]. From the impacts that have been mentioned, it will affect a person's health status and performance when carrying out their daily activities. One of them is affecting the athlete's performance on the agility of their body movements

Agility is a person's ability to change positions in a certain area quickly and precisely without losing balance. There are several factors that affect agility, namely muscle strength, speed, explosive power, reaction time, balance, and coordination. Some of these factors are interrelated, if one has decreased it will automatically affect the performance of the other. When an athlete does exercise regularly, the physiological system in the body will experience adaptation and can increase the physiological capacity of the body, and vice versa, when an athlete does not exercise regularly or stops training continuously, the physiological system in the body experiences adaptation so that it can reduce capacity physiological in the body. These conditions are related to physiological adaptations due to the treatment and the environment at hand, the functions and working mechanisms of these organs will always react in the context of selfadjustment for the creation of homeostasis. Therefore, detraining will affect the level of a person's agility because of the effects of changes in physiological adaptations.

Exercises that are done regularly will increase the ability of the muscles, namely stronger muscle contractions, repeating contractions at a faster rate, and being able to contract for a longer time. These changes are greatly influenced by the intensity and volume of the training session and your fitness level [5] Therefore, someone who exercises regularly will improve neuromascular coordination and muscle quality which will make the movements produced by the body more precise and economical. So as to produce more efficient 
agility. Likewise, someone who does not do activities regularly will cause detraining so that it affects the body's physiological system, especially the strength of muscle contrast which ultimately affects the agility of the body. Especially the agility of the body in the martial arts sport of karate.

Karate is a type of sport that really requires agility. Athletes who are able to change a different position at high speed with good coordination will produce more effective movements and more efficient direction of energy when carrying out movements, therefore it is important to improve.

Based on the background explanation above, the researcher wants to Knowing the relationship between Detraining and the

Body Agility Ability of Karate UKM Athletes, State

University of Malang, thus once it is known, this research can be used as a form of effort to maintain and increase the Agility Ability of Body Movement during the COVID-19 Pandemic.

\section{METHODS}

The research method uses a correlational quantitative design with a causal design. The research was conducted at the Tennis Court, State University of Malang

The sample in this study were 19 athletes of UKM Karate State University of Malang using purposive sampling method

The data collection technique used a questionnaire by conducting interviews with respondents and conducting a shuttle run test. The data that has been grouped will then be entered into the data processing computer application software, namely IBM SPSS Statistic 25

The operational definition of this research uses independent variables (detraining) with questionnaire indicators and the dependent variable (agility) with the shuttle run test indicator. Data analysis techniques in this study used univariate and bivariate data analysis.

\section{RESULTS}

Based on the overall data regarding the effect of detraining during the Covid-19 pandemic on the Agility of the Karate UKM Athletes, State University of Malang, the following results are obtained:

TABLE I. DETRAINING CATEGORIES

\begin{tabular}{|c|c|c|c|}
\hline No & Detraining Category & Amount & Percentage \\
& & & - \\
\hline 1 & Very low & - & $15.8 \%$ \\
\hline 2 & Low & 3 & $26.3 \%$ \\
\hline 3 & Normal & 5 & $47.4 \%$ \\
\hline 4 & High & 9 & $10.5 \%$ \\
\hline 5 & Very high & 19 & $100 \%$ \\
\hline
\end{tabular}

Based on table 1 the data shows that the most results are in the high category with a percentage $(47.4 \%)$
TABLE II. AGILITY CATEGORIES

\begin{tabular}{|c|c|c|c|}
\hline No & Agility Category & Amount & Percentage \\
\hline 1 & Very well & 1 & $5.30 \%$ \\
\hline 2 & Good & 2 & $10.5 \%$ \\
\hline 3 & Moderate & 3 & $15.80 \%$ \\
\hline 4 & Less & 5 & $26.30 \%$ \\
\hline 5 & Very Less & 8 & $42.10 \%$ \\
\hline & Total & 19 & $100 \%$ \\
\hline
\end{tabular}

Based on table 2 the data shows that the highest result is in the very poor category with a percentage $(42.10 \%)$

After the data is processed, the results of the data show that there is a significant relationship between detraining and agility that has been carried out by the researcher. From the results obtained, it shows that the higher the incidence of detraining, the lower the level of one's agility. Based on these results it can be said that the higher the level of detraining, there will be a significant decrease in the agility of the Karate UKM athletes, State University of Malang.

\section{DISCUSSION}

The results showed that the higher the level of detraining, the more it would affect the decrease in the agility of a person's body movements. Detraining is a decrease or loss of the body's physiological adaptation caused by stopping and resting training for a relatively long time so that it affects physical fitness performance. [6]said that detraining is a condition of losing the benefits of the usual exercise or what is commonly called a body condition that is no longer prime and the quality of the body decreases. The adaptations that have been achieved when practicing will diminish or even disappear due to unsustainable and irregular practice.

Detraining caused by several factors, including changes in lifestyle and unbalanced nutritional intake. In the current Covid-19 pandemic, it really supports someone to change their lifestyle and unhealthy eating patterns. Largescale restrictions imposed during a pandemic discourage people from engaging in regular physical activity, which affects their level of physical fitness. As stated by [7] that with sedentary and increasing lifestyle or behavior changes can lead to muscle atrophy due to a mechanical decrease in workload. This can have a negative impact on the body. Lack of physical activity will affect the level of physical fitness, one of which affects the agility level of a person's body movements.

Agility is influenced by flexibility, speed, balance, reaction speed, neuromuscular coordination and muscle strength factors. These factors are a very determining factor in high or low agility abilities. Contraction of muscles requires strength and strength. Strength refers to the power output of muscle contraction and is directly related to the amount of tension generated by muscle contraction, thereby increasing muscle strength in the form of tension levels, hypertrophy, and muscle fiber recruitment.

Exercises that are done regularly will increase the ability of the muscles, namely stronger muscle contractions, repeating contractions at a faster rate, and being able to 
contract for a longer time. Therefore, someone who does regular exercise will improve neuromascular coordination and muscle quality which will make the movements produced by the body more precise and economical so as to produce more efficient agility.

Likewise, someone who does not exercise regularly or stops exercising continuously will cause detraining, thus affecting the body's physiological system, especially on the strength of muscle contrast which ultimately affects the agility of the body. This is in line with research [3] that detraining that occurs for 2 weeks will affect changes in skeletal muscle morphology and reduced production of ATP-PC so that it affects the performance of muscle contraction. The performance of muscle contraction greatly affects the agility of a person's body movements, especially the agility of body movements in karate.

Karate is a type of sport that really requires good body agility. The agility of body movements greatly affects the performance of karate athletes, in addition to muscle strength, cardiovascular endurance, flexibility, speed, explosive power, strength endurance. Athletes who are able to change a different position at high speed with good coordination will produce more effective movements and direct energy when making movements to be more efficient.

Based on the above discussion, it is known that the level of detraining is closely related to the level of agility of a person's body movements. The higher the level of detraining, the more it affects the decrease in one's agility level. The results of this study are in line with the theories that have been put forward by previous experts, which explain that detraining can occur in the neumuscular, autonomic, metabolic, and cardiovascular systems, automatically affecting all components of physical fitness including muscle, speed, and strength, balance. coordination, flexibility and cardiovascular endurance (Lennon et al, 2018). Meanwhile, the factors that have been described above are the factors that affect agility. When one of the factors changes, the body's physiological system will adapt so that it will affect the ability of a person's body agility.

In karate, the element of agility is needed by an athlete to anticipate attacks from opponents. With good agility, it opens up opportunities for a player to be able to move in all directions quickly and precisely to build attack strategies and save themselves from opponent attacks. Good body agility greatly affects the performance of an athlete in a sport Karate martial arts. Thus, it can be concluded that a karate athlete when competing must have good body agility skills in order to get a big advantage when carrying out attacks, easily switch and avoid opponents, and know the distance or range of steps to attack or defend.

Agility (agility) is the body's ability to change direction quickly and precisely without disturbing balance or losing balance. Thus an explosive movement will greatly allow a karate martial artist to master all movements in the karate martial arts movement. The agility component is closely related to the components of speed and coordination. As stated [9] that agility for a player is closely related to the ability to change direction at high speed. Someone who is able to change from one position to a different position, with high speed and good coordination of motion, means that his agility is quite good. Agility is needed in the sport of karate, especially speed in movement and speed of reaction to a given stimulus.

Basically, agility is owned by each individual, but it needs to be improved to achieve the quality of work with various efforts so that the expected achievements in a sport can be achieved properly. Exercises that are gradual and systematic and well programmed are the right solution to improve the elements of physical condition. Likewise, when a person does not exercise regularly it will affect the decrease in physical conditions related to the body's physiological system or what is commonly called detraining. As stated by [10]that the principle of periodization of training applies to the principle of reversibility, namely the decrease or return of the body to its initial condition The adaptation that has been achieved during training will decrease and even disappear due to unsustainable and irregular practice. Detraining results in a significant decrease in fitness and muscle mass so that it affects the agility of an individual's body movement, especially in the karate martial arts sport which requires good agility.

In research [11] explained that detraining causes several adverse effects on the body, including reduced leg muscle mass and increased visceral fat. The impact of this will affect the quality of the strength of muscle contraction so that it greatly affects the level of agility of the karate athletes.

\section{CONCLUSION}

Based on the results of the research that has been done, it can be concluded that the incidence of detraining has a significant relationship to the level of agility of the Karate UKM athletes, State University of Malang. This is due in part to the lack of physical activity during the Covid-19 pandemic. Changes in an inactive lifestyle will support detraining.

The occurrence of detraining in a person can affect the body's physiological system, especially in neuromascular coordination and the strength of the quality of muscle contraction which ultimately affects the agility of the body. Thus the higher the level of detraining, the more it affects the decrease in the level of agility in a person.

\section{ACKNOWLEDGMENT}

The author is very grateful to the mentors and Karate Athletes State University of Malang involved in the research. Hopefully this article is useful and adds insight to the readers.

\section{REFERENCES}

Tim Kerja Kementerian Dalam Negeri, "Pedoman Umum Menghadapi Pandemi Covid-19 Bagi Pemerintah Daerah," J. Chem. Inf. Model., 2020.

[2] A. V. Mattioli and M. Ballerini Puviani, "Lifestyle at Time of COVID-19: How Could Quarantine Affect Cardiovascular Risk," Am. J. Lifestyle Med., vol. 14, no. 3, pp. 240-242, 2020.

[3] C. H. Joo, "The effects of short term detraining and retraining on 
physical fitness in elite soccer players," PLoS One, vol. 13, no. 5, pp. 1-15, 2018.

[4] R. Zacca et al., "Effects of detraining in age-group swimmers performance, energetics and kinematics," J. Sports Sci., vol. 37, no. 13, pp. 1490-1498, 2019.

[5] S. D. P. Akbar, D. Marisa, and A. Husairi, "Perbedaan Tekanan Darah dan Denyut Nadi Sebelum dan Sesudah Latihan Fisik Intensitas Sedang Pada Pemain Futsal," Dep. Biomedik, Fak. Kedokteran, Univ. Lambung Mangkurat, 2019.

[6] B. Indrayana and E. Yuliawan, "Penyuluhan Pentingnya Peningkatan Vo2Max Guna Meningkatkan Kondisi Fisik Pemain Sepakbola Fortuna Fc Kecamatan Rantau Rasau," iImiah Sport Coach. Educ., 2019.

[7] I. Mujika and S. Padilla, "Detraining: Loss of training induced physiological and performance adaptation. Part I. Short term insufficient training stimulus," Sport. Med., vol. 30, no. 2, pp. 79-
87,2000

[8] S. Lennon, G. Ramdharry, and G. Verheyden, Physical Management for Neurological Conditions, Fourth edi. Adelaide, Australia: ELSEVIER, 2018.

[9] M. Dimyati, M. Komarudin, E. Susanto, and J. Purwanto, "The Capabilities of Sports Education Teachers in Making Character Oriented Lesson Plans and Learning Practices," vol. 278, no. YISHPESS, pp. 190-193, 2019.

[10] I. Mujika and S. Padilla, "Detraining: Loss of Training-Induced Physiological and Performance Adaptations. Part I," Sport. Med., vol. 30, no. 2, pp. 79-87, 2000.

[11] Y. C. Sung, Y. H. Liao, C. Y. Chen, Y. L. Chen, and C. C. Chou, "Acute changes in blood lipid profiles and metabolic risk factors in collegiate elite taekwondo athletes after short-term de-training: A prospective insight for athletic health management," Lipids Health Dis., vol. 16, no. 1, pp. 1-10, 2017. 